\title{
Removal of Aqueous Para-Aminobenzoic Acid Using a Compartmental Electro-Peroxone Process
}

\author{
Donghai $\mathrm{Wu}^{1}{ }^{1}$, Yuexian $\mathrm{Li}^{1}{ }^{\text {, Guanghua Lu }}{ }^{1, *}$, , Qiuhong Lin ${ }^{1}$, Lei Wei ${ }^{2}$ and Pei Zhang ${ }^{2}$ \\ 1 Key Laboratory of Integrated Regulation and Resource Development on Shallow Lakes of Ministry of \\ Education, College of Environment, Hohai University, Nanjing 210098, China; wdh1018@hhu.edu.cn (D.W.); \\ liyuexian109@163.com (Y.L.); lin_qh@yeah.net (Q.L.) \\ 2 Hydrology and Water Resources Bureau of Henan Province, Zhengzhou 450004, China; \\ weileilazio@hotmail.com (L.W.); zhpwhj2006@163.com (P.Z.) \\ * Correspondence: ghlu@hhu.edu.cn
}

check for updates

Citation: Wu, D.; Li, Y.; Lu, G.; Lin, Q.; Wei, L.; Zhang, P. Removal of Aqueous Para-Aminobenzoic Acid Using a Compartmental Electro-Peroxone Process. Water 2021, 13, 2961. https://doi.org/10.3390/ w13212961

Academic Editor: Sergi Garcia-Segura

Received: 28 September 2021

Accepted: 18 October 2021

Published: 20 October 2021

Publisher's Note: MDPI stays neutral with regard to jurisdictional claims in published maps and institutional affiliations.

Copyright: (c) 2021 by the authors. Licensee MDPI, Basel, Switzerland. This article is an open access article distributed under the terms and conditions of the Creative Commons Attribution (CC BY) license (https:/ / creativecommons.org/licenses/by/ $4.0 /)$.
Abstract: The presence of emerging contaminant para-aminobenzoic acid (PABA) in the aquatic environment or drinking water has the potential to harm the aquatic ecosystem and human health. In this work, the removal of aqueous PABA by a compartmental electro-peroxone (E-peroxone) process was systematically investigated from the kinetic and mechanism viewpoints. The results suggest that single electrolysis or ozonation was inefficient in PABA elimination, and the combined Eperoxone yielded synergistic target pollutant degradation. Compared to the conventional E-peroxone oxidation, the sequential cathodic reactions, followed by anodic oxidations, improved the PABA removal efficiency from $\sim 63.6 \%$ to $\sim 89.5 \%$ at a 10 -min treatment, and the corresponding pseudo first-order kinetic reaction rate constant increased from $\sim 1.6 \times 10^{-3}$ to $\sim 3.6 \times 10^{-3} \mathrm{~s}^{-1}$. Moreover, the response surface methodology (RSM) analysis indicated that the appropriate increase of inlet ozone concentration, applied current density, initial solution $\mathrm{pH}$ value, and solution temperature could accelerate the PABA degradation, while the excess of these operational parameters would have a negative effect on the treatment efficiency. The comparation tests revealed that the coupling of electrolysis and ozonation could synergistically produce hydroxyl radicals (HO•) and the separation of cathodic reactions and anodic oxidations further promoted the HO• generation, which was responsible for the enhancement of PABA elimination in the compartmental E-peroxone process. These observations imply that the compartmental E-peroxone process has the potential for aqueous micropollutants elimination, and the reaction conditions that favor the reactive oxygen species generation are critical for the treatment efficiency.

Keywords: electro-peroxone; para-aminobenzoic acid; response surface methodology; hydroxyl radicals; elimination

\section{Introduction}

Ultraviolet (UV) filters are emerging contaminants that have drawn extensive attention, due to their potential risks to ecosystems and human health [1-3]. Para-aminobenzoic acid (PABA) is one of the most widely used UV filters. The continuous discharge of PABA into the aquatic environment via personal care applications has induced particular concerns [4]. Evidence has shown that PABA could increase the photosensitivity [5]. Consequently, the removal of PABA from water and wastewater is of great importance.

In the past few years, advanced oxidation processes (AOPs) have been investigated to remove PABA from water [6-9]. AOPs can produce high reactive species to oxidize organic compounds completely. However, the single process usually has some shortcomings, such as high cost and inefficient treatment. The combination of several methods may yield a higher performance than individual processes. Recently, electro-peroxone (Eperoxone) - the combination of ozonation and electrolysis with a carbon-based cathodehas been recommended as an excellent water treatment technology with low cost and 
mild operating conditions [10]. An important characteristic of E-peroxone is that ozone and $\mathrm{H}_{2} \mathrm{O}_{2}$ can be electro-generated in situ to produce hydroxyl radicals (HO•), thus the storage of reagents can be avoided [11,12]. Moreover, E-peroxone exhibited a much better performance than single ozonation or electrolysis, and was shown to be more costeffective [13], convenient and safe [14,15]. In the E-peroxone process, contaminants can be directly transformed by electron transfer on the electrode surface and degraded by the introduced $\mathrm{O}_{3}$ and intermediated $\mathrm{HO} \bullet$ [16]. Thanks to the employment of carbon-based cathode, the two-electron reduction of oxygen can produce $\mathrm{H}_{2} \mathrm{O}_{2}$ in situ to react with $\mathrm{O}_{3}$, and then significantly enhance $\mathrm{O}_{3}$ decomposition to form $\mathrm{HO} \bullet$. It is possible to improve the treatment efficiency by cathode modification [17].

Although the E-peroxone process has many advantages, it still contains some deficiencies, such as the low ozone utilization and the lack of a large area cathode. Hitherto, the reported E-peroxone processes were mainly performed in semi-batch reactors, which fed $\mathrm{O}_{2} / \mathrm{O}_{3}$ mixed gas into an undivided electrochemical reactor [18]. As restricted to the preparation method, the gas diffusion cathodes (GDCs) used in the E-peroxone process had a small area. This means that the mass transfer of reactants to the electrodes might be restricted, and the political application of this technology in water and wastewater treatment is difficult. Moreover, due to the very short gas-liquid contact time, only a small part of the introduced ozone could be used [19]. Therefore, developing an efficient reactor and optimizing technique parameters were recommended to improve the E-peroxone treatment efficiency $[20,21]$. However, few systematic studies have investigated the use of this coupled process for the emerging contaminant PABA elimination, and the effects of cathodic and anodic reactions' separation on E-peroxone treatment efficiency is largely unknown.

The aims of this study were: (1) Evaluating the effectiveness of compartmental Eperoxone treatment in aqueous PABA removal; (2) Investigating and optimizing the effects of operational parameters (i.e., inlet ozone concentration, applied current density, initial solution $\mathrm{pH}$, and solution temperature) on treatment efficiency by response surface methodology (RSM); (3) Elucidating the possible oxidation mechanisms via oxidants determination and their generation pathways analysis.

\section{Materials and Methods}

\subsection{Chemicals and Reagents}

The cation-exchange membrane (CEM) was purchased from Hangzhou Lvhe Environmental Technology Co., Ltd., Hangzhou, Zhejiang, China. PABA (its characteristics and structure were listed in Table 1), potassium indigo trisulfonate and p-chlorobenzoic acid ( $p$ CBA) were supplied by Sigma Aldrich, St. Louis, MI, USA. Multi-walled CNTs (30-50 nm of outer diameter, Purity $>98 \%$ ) were provided by Chengdu Organic Chemistry Co., Ltd., Chinese Academy of Sciences, Chengdu, Sichuan, China. All the chemical reagents were at least of analytical grade without further purification.

Table 1. Characteristics of the PABA.

\begin{tabular}{ccc}
\hline Common Name & Chemical Structure & $\begin{array}{c}\mathbf{M}_{\mathbf{W}} \\
(\mathbf{g} / \mathbf{m o l})\end{array}$ \\
\hline $\begin{array}{c}p \text {-Aminobenzoic acid } \\
\left(\mathrm{C}_{7} \mathrm{H}_{7} \mathrm{NO}_{2}\right)\end{array}$ & $\mathrm{HOOC}$ & 137.14 \\
\hline
\end{tabular}

\subsection{Experimental Apparatus and Conditions}

Experiments were performed in a separated E-peroxone system that contained a divided electrochemical reactor and a feed tank (Figure 1). In the center of the electrochemical reactor there was a removable CEM, which divided the reactor into two chambers. Each chamber had a width of $30 \mathrm{~mm}$, a length of $30 \mathrm{~mm}$, and a height of $30 \mathrm{~mm}$. A $5 \mathrm{~cm}^{2}$ 
ferrite modified carbon nanotubes-based GDC and a Pt anode were parallelly fixed in the cathode chamber and anode chamber, respectively. The GDC was prepared according to the method described elsewhere [17]. The gap between two electrodes was $15 \mathrm{~mm}$, and the constant current was provided by a DC power supply (KPS-3030DA, Atten Technology, Shenzhen, Guangdong, China). Firstly, the raw water $(1.0 \mathrm{~L})$ was pumped from the feed tank to the cathode chamber. After sequential passing through the cathode chamber and anode chamber, the solution flowed back into the feed tank. The whole reaction system was kept circulating by a peristaltic pump (YZ1515, Tianjin Xieda Exectron Co., Ltd., Tianjin, China). Ozone was produced from pure oxygen by a laboratory ozone generator (WH-H-Y5, Wohuan Technology Industry Co., Ltd., Nanjing, Jiangsu, China), which could adjust the produced $\mathrm{O}_{3}$ concentration by changing the power. In the ozone related process, $0.2 \mathrm{~L} / \mathrm{min}$ ozonized gas was fed into the cathode chamber via a bubble diffuser that was situated under the cathode, and equal pure oxygen was used in the sole electrolysis system. For comparison, the CEM was removed from the electrochemical reactor in the termed conventional E-peroxone tests.

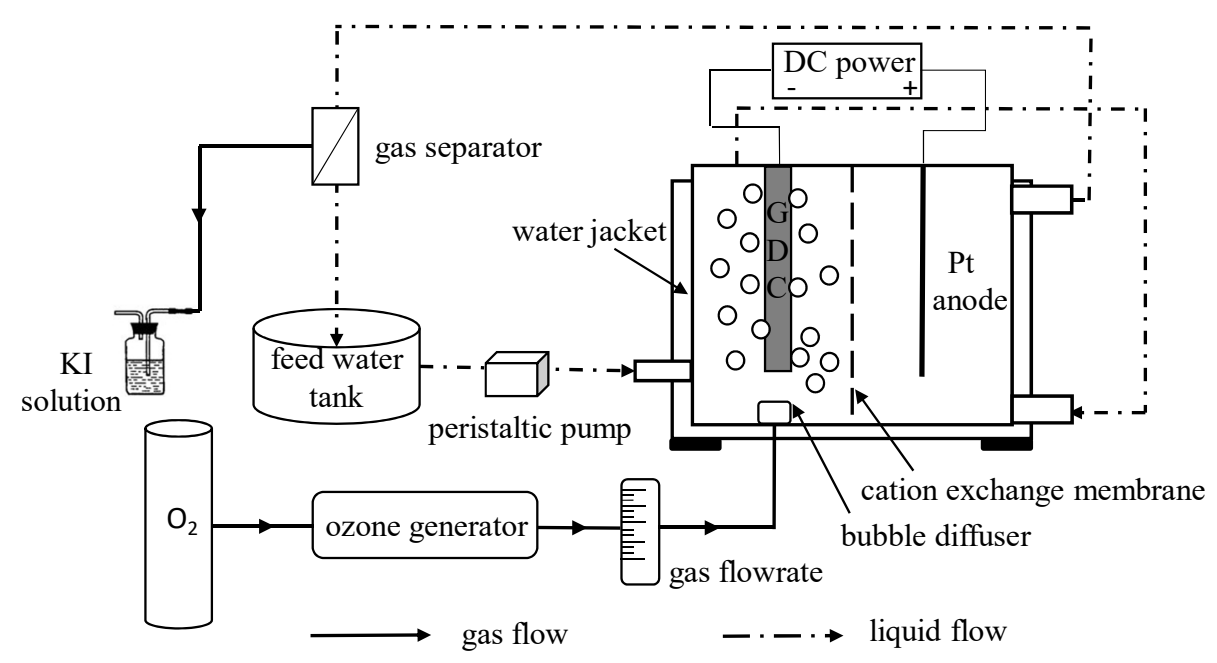

Figure 1. Schematic of experimental setup.

In all experiments, $50 \mathrm{mmol} / \mathrm{L} \mathrm{Na}_{2} \mathrm{SO}_{4}$ was employed as the supporting electrolyte. Unless otherwise indicated, the tests were performed at ambient temperature $\left(25 \pm 2{ }^{\circ} \mathrm{C}\right)$. The initial solution $\mathrm{pH}$ was adjusted using concentrated $\mathrm{H}_{2} \mathrm{SO}_{4}$ or $\mathrm{NaOH}$, and a water jacket outside the electrochemical cell was employed for controlling the solution's temperature. Samples were harvested from the feed tank at a predetermined time interval, and $2 \mu \mathrm{L}$ of $0.1 \mathrm{~mol} / \mathrm{L} \mathrm{Na}_{2} \mathrm{~S}_{2} \mathrm{O}_{3}$ in a $1 \mathrm{~mL}$ sample was added to stop the oxidative reactions.

\subsection{Analytical Methods}

The gaseous ozone concentration was detected by the iodometric method [22]. The $\mathrm{H}_{2} \mathrm{O}_{2}$ was measured with the titanium salt spectrophotometry method [23]. The generation of $\mathrm{HO} \bullet$ was calculated indirectly by the $p$ CBA method [24]. The steady-state concentrations of $\mathrm{HO} \bullet$ could be calculated from the known rate constant for the reaction of $p \mathrm{CBA}$ with $\mathrm{HO} \bullet$ and the determined pseudo first-order rate constant of $p \mathrm{CBA}$ decay. The solution $\mathrm{pH}$ value and temperature were measured by a Thermo Orion $868 \mathrm{~m}$. PABA concentration was determined with high-performance liquid chromatography (HPLC, Waters Alliance e2998, Milford, MA, USA) performed on a Nov-pack C18 column $(4.6 \mathrm{~mm} \times 150 \mathrm{~mm}$, particle size $4 \mu \mathrm{m})$ at $30{ }^{\circ} \mathrm{C}$. The mobile phase consisted of $40 \%$ methanol and $60 \%$ water $(0.5 \%$ acetic acid, $v / v$ ) with a flow rate of $1 \mathrm{~mL} / \mathrm{min}$. The injection volume was $10 \mu \mathrm{L}$ and the detection wavelength was $282 \mathrm{~nm}$. 


\section{Results and Discussion}

\subsection{Degradation of PABA}

The degradation performances of PABA by various processes were shown in Figure 2a. For the control test without current and ozone application, 12\% PABA removal was detected, implying that the adsorption effects of electrodes and the reactor were marginal. Neither single electrolysis nor ozonation could degrade PABA effectively, only $\sim 22.9 \%$ and $\sim 34.7 \%$ eliminations were observed at 10-min treatments, respectively. Synergistic contaminant destruction was obtained in the compartmental E-peroxone system, $\sim 89.5 \%$ PABA was degraded within $10 \mathrm{~min}$. In contrast, when the CEM was removed from the electrochemical cell, the PABA removal efficiency decreased significantly, $\sim 63.6 \%$ degradation was detected in the conventional E-peroxone process. Moreover, the kinetic analysis indicates that the PABA degradation reactions in all the above processes followed the pseudo first-order kinetics (Figure $2 b$ ). The calculated rate constants are as follows: compartmental E-peroxone $\left(\sim 3.6 \times 10^{-3} \mathrm{~s}^{-1}\right)>$ conventional E-peroxone $\left(\sim 1.6 \times 10^{-3} \mathrm{~s}^{-1}\right)$ $>$ ozonation $\left(\sim 0.8 \times 10^{-3} \mathrm{~s}^{-1}\right)>$ electrolysis $\left(\sim 0.4 \times 10^{-3} \mathrm{~s}^{-1}\right)$. Furthermore, the synergistic effect was quantitatively analyzed by synergistic index (f) according to Equation (1), and the calculated $\mathrm{f}$ of compartmental E-peroxone system was $\sim 3$.

$$
\mathrm{f}=\frac{k_{\text {compartmental E-peroxone }}}{k_{\text {ozonation }}+k_{\text {electrolysis }}}
$$
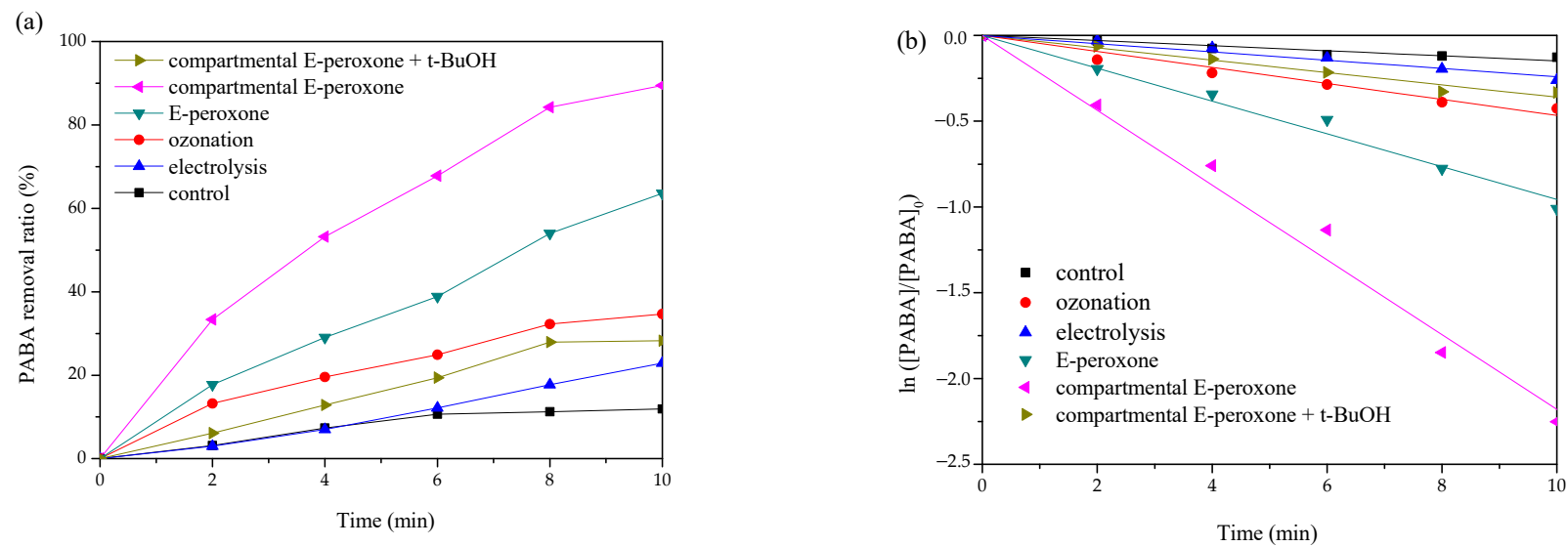

Figure 2. Comparison of PABA degradation in various oxidation processes: (a) removal ratio and (b) the pseudo first-order reaction kinetics (Initial PABA concentration $=\sim 10 \mathrm{mg} / \mathrm{L}$; Gas flow rate $=0.2 \mathrm{~L} / \mathrm{min}$; Inlet $\mathrm{O}_{3}$ concentration $=\sim 20 \mathrm{mg} / \mathrm{L}$; Applied current $=20 \mathrm{~mA} / \mathrm{cm}^{2}$; Initial solution $\mathrm{pH}=6.9$; Temperature $=25 \pm 2{ }^{\circ} \mathrm{C}$ ).

In general, because of the restricted mass transfer at electrodes, a long time is needed for sole electrolysis treatment, and unsatisfied degradation efficiency has been reported for the electrolysis of many pollutants $[25,26]$. Ozone is a selective oxidant that can oxidize ozone-reactive contaminants quickly but is inefficient at the ozonation of ozone-resistant compounds. PABA has a carboxyl functional group (Table 1), which is difficult oxidized by ozone [27]. Thus, sole electrolysis or ozonation exhibited a low PABA removal efficiency. In the E-peroxone system, the reduction of oxygen at cathode could, in-situ, generate $\mathrm{H}_{2} \mathrm{O}_{2}$, and further initiate the peroxone reactions (Equations (2) and (3)) [12]. The produced $\mathrm{HO} \bullet$ is an excellent and unselective oxidant that can degrade most organic compounds completely. Therefore, tert-butyl alcohol ( $\mathrm{t}-\mathrm{BuOH})$ was employed as a scavenger to verify the contribution of $\mathrm{HO} \bullet$ in the compartmental E-peroxone process. As shown in Figure 2a, the presence of $\mathrm{t}-\mathrm{BuOH}$ profoundly decreased the PABA removal ratio, implying that PABA degradation mainly followed the $\mathrm{HO} \bullet$ oxidation mechanism. The contributions of various factors on PABA removal in the compartmental E-peroxone process were identified in Figure 3.

$$
\mathrm{O}_{2}+2 \mathrm{H}^{+}+2 \mathrm{e}^{-} \rightarrow \mathrm{H}_{2} \mathrm{O}_{2}
$$




$$
2 \mathrm{H}_{2} \mathrm{O}_{2}+2 \mathrm{O}_{3} \rightarrow \mathrm{H}_{2} \mathrm{O}+3 \mathrm{O}_{2}+\mathrm{HO}_{2} \bullet+\mathrm{HO} \bullet
$$

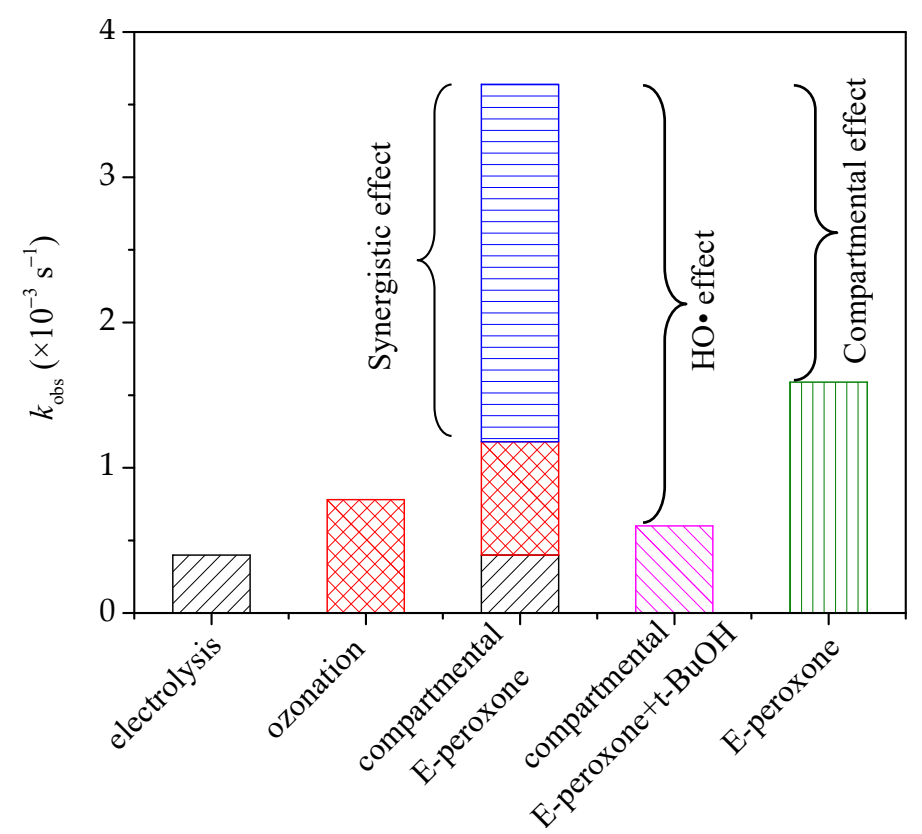

Figure 3. The pseudo first-order reaction rate constants of various treatment processes. (Gas flow rate $=0.2 \mathrm{~L} / \mathrm{min}$; Inlet $\mathrm{O}_{3}$ concentration $=\sim 20 \mathrm{mg} / \mathrm{L} ;$ Applied current $=20 \mathrm{~mA} / \mathrm{cm}^{2}$; Initial solution $\mathrm{pH}=6.9$; Temperature $=25 \pm 2{ }^{\circ} \mathrm{C}$ ).

\subsection{Effects of Operational Parameters}

\subsubsection{Model Building and Statistical Analyses}

Central composite design (CCD), a widely used form of RSM [28,29], was applied to investigate the effects of the experimental variables and their interactions on the response functions. The initial solution $\mathrm{pH}\left(x_{1}\right)$, inlet $\mathrm{O}_{3}$ concentration $\left(x_{2}\right)$, cathodic current density $\left(x_{3}\right)$ and reaction temperature $\left(x_{4}\right)$ were selected as the independent variables, and the dependent variable was PABA removal efficiency $(y)$. A 4-factor and 5-level CCD consisting of 30 experimental runs was performed, and the results were shown in Table 2. A second order polynomial response equation (Equation (4)) was applied to relate the empirical relationship between the independent and dependent variables.

$$
y=\beta_{0}+\sum_{i=1}^{k} \beta_{i} x_{i}+\sum_{i=1}^{k} \beta_{i i} x_{i}^{2}+\sum_{i=1}^{k-1} \sum_{j=2}^{k} \beta_{i j} x_{i} x_{j}+\varepsilon(i<j),
$$

where $y$ is the response factor, $x_{i}$ and $x_{j}$ are independent variables, $k=4 ; \beta_{0}, \beta_{i}, \beta_{i i}, \beta_{i j}$ are the regression coefficients for intercept, linearity, square, and interaction, respectively; $\varepsilon$ represents the residual term. 
Table 2. Design matrix and the experimental responses.

\begin{tabular}{|c|c|c|c|c|c|}
\hline $\begin{array}{l}\text { Exp. } \\
\text { no. }\end{array}$ & $\begin{array}{l}\text { Initial } \\
\mathrm{pH}\end{array}$ & $\begin{array}{c}\mathrm{O}_{3} \text { Dosage } \\
(\mathrm{mg} / \mathrm{L})\end{array}$ & $\begin{array}{l}\text { Current Density } \\
\qquad\left(\mathrm{mA} / \mathrm{cm}^{2}\right)\end{array}$ & $\begin{array}{c}\text { Reaction } \\
\text { Temperature }\left({ }^{\circ} \mathrm{C}\right)\end{array}$ & $\begin{array}{c}\text { Removal } \\
\text { Efficiency (\%) }\end{array}$ \\
\hline 1 & 5 & 25 & 20 & 25 & 74.9 \\
\hline 2 & 9 & 15 & 20 & 25 & 84.9 \\
\hline 3 & 5 & 25 & 40 & 15 & 61.2 \\
\hline 4 & 9 & 25 & 40 & 15 & 69.1 \\
\hline 5 & 7 & 20 & 30 & 20 & 82.0 \\
\hline 6 & 9 & 15 & 20 & 15 & 59.1 \\
\hline 7 & 7 & 20 & 30 & 20 & 81.5 \\
\hline 8 & 7 & 30 & 30 & 20 & 85.5 \\
\hline 9 & 9 & 25 & 20 & 25 & 89.1 \\
\hline 10 & 7 & 20 & 30 & 30 & 93.0 \\
\hline 11 & 5 & 25 & 40 & 25 & 79.2 \\
\hline 12 & 5 & 25 & 20 & 15 & 58.1 \\
\hline 13 & 7 & 20 & 30 & 20 & 81.1 \\
\hline 14 & 5 & 15 & 20 & 25 & 72.5 \\
\hline 15 & 7 & 20 & 30 & 20 & 81.6 \\
\hline 16 & 9 & 15 & 40 & 15 & 65.3 \\
\hline 17 & 7 & 20 & 50 & 20 & 76.2 \\
\hline 18 & 11 & 20 & 30 & 20 & 87.8 \\
\hline 19 & 7 & 20 & 30 & 20 & 81.8 \\
\hline 20 & 9 & 25 & 20 & 15 & 64.4 \\
\hline 21 & 7 & 20 & 30 & 20 & 81.7 \\
\hline 22 & 5 & 15 & 20 & 15 & 44.9 \\
\hline 23 & 7 & 20 & 10 & 20 & 72.6 \\
\hline 24 & 5 & 15 & 40 & 25 & 77.3 \\
\hline 25 & 3 & 20 & 30 & 20 & 58.6 \\
\hline 26 & 7 & 20 & 30 & 10 & 50.7 \\
\hline 27 & 5 & 15 & 40 & 15 & 57.1 \\
\hline 28 & 9 & 25 & 40 & 25 & 94.9 \\
\hline 29 & 9 & 15 & 40 & 25 & 88.0 \\
\hline 30 & 7 & 10 & 30 & 20 & 69.9 \\
\hline
\end{tabular}

Based on the experimental data analysis by the Design-Expert software, the following quadratic polynomial response equation (Equation (5)) was obtained.

$$
\begin{gathered}
y=81.62+6.17 x_{1}+3.04 x_{2}+2.14 x_{3}+11.09 x_{4}-0.088 x_{1} x_{2}-0.29 x_{1} x_{3}+1.03 x_{1} x_{4}-0.52 x_{2} x_{3}-0.69 x_{2} x_{4} \\
-0.51 x_{3} x_{4}-2.61 x_{1}^{2}-1.49 x_{2}{ }^{2}-2.31 x_{3}{ }^{2}-2.95 x_{4}{ }^{2}
\end{gathered}
$$

According to Equation (5), the influences of various parameters on PABA degradation can be calculated, and an increasing order of the four independent variables is cathodic current density $\left(x_{3}\right)<$ inlet $\mathrm{O}_{3}$ concentration $\left(x_{2}\right)<$ initial solution $\mathrm{pH}\left(x_{1}\right)<$ reaction temperature $\left(x_{4}\right)$. It is also noted that there were positive or negative interaction effects between different parameters. Moreover, analysis of variance (ANOVA) checked the applicability of the model (Table 3). The model F-value was 38.79 and the $p$ value $<0.0001$, indicating that the model was statistically significant. Models with high determination coefficients $\left(\mathrm{R}^{2}\right)$ revealed that $97.31 \%$ of the variability in the data could be in a good prediction with Equation (5). The low coefficient of variation (3.96\%) ensured the experimental values had high accuracy and reliability. The normal residuals fall along a straight line (Figure S1), indicating that a response transformation was not required and there was no apparent problem with normality. 
Table 3. ANOVA and fit statistic for the quadratic model.

\begin{tabular}{cccccc}
\hline Source & $\begin{array}{c}\text { Sum of } \\
\text { Squares }\end{array}$ & $\begin{array}{c}\text { Degree of } \\
\text { Freedom }\end{array}$ & $\begin{array}{c}\text { Mean } \\
\text { Square }\end{array}$ & $f$-Value & $p$-Value \\
\hline Model & 4689.39 & 14 & 334.96 & 38.79 & $<0.0001$ \\
$x_{1}$ & 912.67 & 1 & 912.67 & 105.68 & $<0.0001$ \\
$x_{2}$ & 222.04 & 1 & 222.04 & 25.71 & 0.0001 \\
$x_{3}$ & 110.08 & 1 & 110.08 & 12.75 & 0.0028 \\
$x_{4}$ & 2952.60 & 1 & 2952.60 & 341.90 & $<0.0001$ \\
$x_{1} x_{2}$ & 0.12 & 1 & 0.12 & 0.014 & 0.9068 \\
$x_{1} x_{3}$ & 1.32 & 1 & 1.32 & 0.15 & 0.7011 \\
$x_{1} x_{4}$ & 16.81 & 1 & 16.81 & 1.95 & 0.1833 \\
$x_{2} x_{3}$ & 4.41 & 1 & 4.41 & 0.51 & 0.4858 \\
$x_{2} x_{4}$ & 7.56 & 1 & 7.56 & 0.88 & 0.3642 \\
$x_{3} x_{4}$ & 4.20 & 1 & 4.20 & 0.49 & 0.4961 \\
$x_{1}{ }^{2}$ & 186.91 & 1 & 186.91 & 21.64 & 0.0003 \\
$x_{2}{ }^{2}$ & 60.52 & 1 & 60.52 & 7.01 & 0.0183 \\
$x_{3}{ }^{2}$ & 146.41 & 1 & 146.41 & 16.95 & 0.0009 \\
$x_{4}{ }^{2}$ & 238.36 & 1 & 238.36 & 27.60 & $<0.0001$ \\
Residual & 129.54 & 15 & 8.64 & & \\
Lack of fit & 129.07 & 10 & 12.91 & 137.80 & $<0.0001$ \\
Pure error & 0.47 & 5 & 0.094 & & \\
Corr. total & 4818.93 & 29 & & & \\
$\mathrm{R}^{2}=0.9731$ & $\mathrm{R}^{2}$ Adj $=0.9480$ & $\mathrm{R}^{2}$ pre $=0.8456$ & $\mathrm{C} . \mathrm{V} . \%=3.96$ & & \\
\hline
\end{tabular}

\subsubsection{Response Surface and Counter Plots}

Based on the RSM analysis, the three-dimensional response surface (Figure 4) and contour plots (Figure S2) were obtained to visually display the overall interactions. Briefly, an appropriate increase of all the investigated parameters could accelerate the PABA degradation, but the extreme high values of these variables exhibited inhibitory effects. Theoretically, the increase of these four parameters has both positive and negative effects on the E-peroxone treatment efficiency. When the inlet gaseous ozone concentration increased, the gas-liquid mass transfer of ozone would be enhanced [30], which was beneficial to ozonation and peroxone oxidation. However, due to the short contacting time and the limited ozone solubility in water, the utilization of ozone was restricted, and exorbitant gaseous ozone concentration did not further facilitate contaminant degradation. In addition, the possibility of $\mathrm{HO} \bullet$ consumption by ozone (Equation (6)) should also be noticed; it would lower the oxidation capacity in the system [24]. The positive effects of high current density includes enhanced anodic oxidations and cathodic reductions, but the excess $\mathrm{H}_{2} \mathrm{O}_{2}$ could also consume the $\mathrm{HO} \bullet$ and reduce the treatment efficiency [18]. Although the increase of the solution temperature would reduce the solubility of ozone and oxygen, the reaction activation energies could also be reduced to stimulate the PABA degradation. Compared with acidic environment, an alkaline environment is more favorable for ozonation and peroxone to produce reactive radicals [31]. Nevertheless, the low proton concentration would affect the $\mathrm{H}_{2} \mathrm{O}_{2}$ accumulation rate (Equation (2)).

$$
\begin{gathered}
\mathrm{O}_{3}+\mathrm{HO} \bullet \rightarrow \mathrm{O}_{2}+\mathrm{HO}_{2} \bullet \\
\mathrm{HO}_{2}{ }^{-}+\mathrm{HO} \bullet \rightarrow \mathrm{HO}_{2} \bullet+\mathrm{OH}^{-}
\end{gathered}
$$



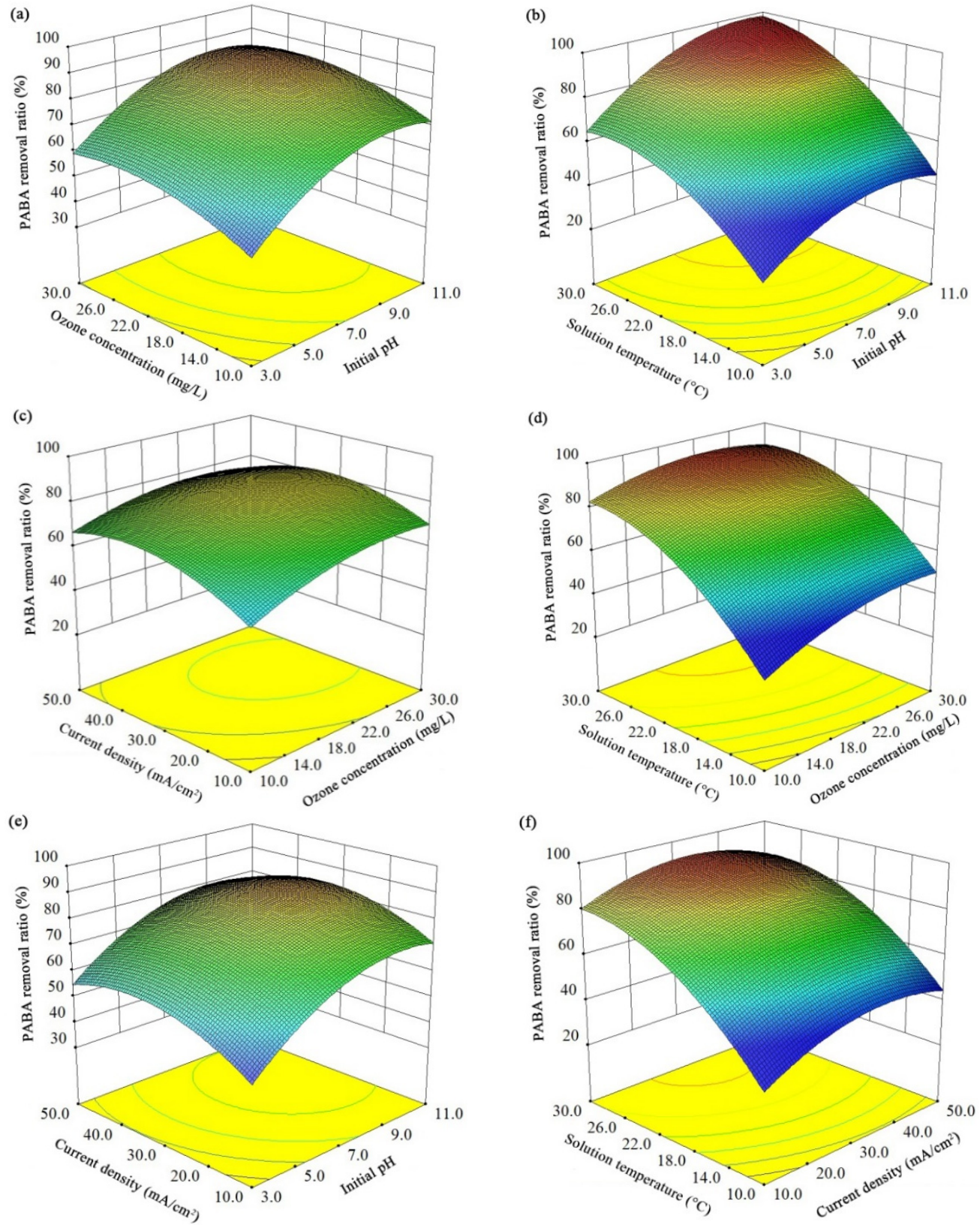

Figure 4. Response surface showing the PABA elimination efficiency as a function of two independent variables at 10-min treatment: (a) inlet gaseous ozone concentration and initial solution $\mathrm{pH},(\mathbf{b})$ solution temperature and initial solution $\mathrm{pH},(\mathbf{c})$ current density and inlet gaseous ozone concentration, (d) solution temperature and inlet gaseous ozone concentration, (e) current density and initial solution $\mathrm{pH},(\mathbf{f})$ solution temperature and current density.

Since the mechanisms of PABA degradation affected by different parameters were correlated, there were interaction effects between various variables. For instance, the negative influence of high current density was more obvious when the solution had a high initial $\mathrm{pH}$. The increase of solution $\mathrm{pH}$ could promote ozone react with $\mathrm{OH}^{-}$to produce $\mathrm{HO}_{2}{ }^{-}$, which would then react with ozone to generate $\mathrm{HO}$. Similarly, with the increase of applied current density, the enhanced cathodic $\mathrm{O}_{2}$ reduction would stimulate the $\mathrm{H}_{2} \mathrm{O}_{2}$ formation, and the peroxone reactions would be accelerated. However, the excess production of $\mathrm{H}_{2} \mathrm{O}_{2} / \mathrm{HO}_{2}{ }^{-}$would cause the consumption of $\mathrm{HO} \bullet$ in the E-peroxone process (Equation (7)), and the PABA elimination rate would be decreased. Likewise, the positive effect of the high solution temperature was more remarkable when the applied 
current density was less than $35 \mathrm{~mA} / \mathrm{cm}^{2}$. As mentioned above, the increase of solution temperature could activate ozone and $\mathrm{H}_{2} \mathrm{O}_{2}$ molecules, improving the related reaction rates. With the initial $\mathrm{pH}$ of $\sim 7$ and inlet ozone concentration of $\sim 20 \mathrm{mg} / \mathrm{L}$, more than $90 \%$ PABA removal was obtained in the region between $26-30{ }^{\circ} \mathrm{C}$ solution temperature and $27-40 \mathrm{~mA} / \mathrm{cm}^{2}$ applied current density. However, the high temperature would also reduce the solubility of $\mathrm{O}_{3} / \mathrm{O}_{2}$. When there was insufficient aqueous ozone to initiate the peroxone reactions, the excess $\mathrm{H}_{2} \mathrm{O}_{2}$ would act as an $\mathrm{HO} \bullet$ scavenger to reduce the oxidation ability of the E-peroxone system.

\subsubsection{Optimization of Compartmental E-Peroxone Process}

The response optimizer was employed to optimize the reaction conditions. The independent variables were selected to be "in the range", and the PABA elimination efficiency was defined as "maximize". The calculated optimum values of the operational parameters were initial solution $\mathrm{pH} 10.1$, inlet gaseous $\mathrm{O}_{3}$ concentration $22.5 \mathrm{mg} / \mathrm{L}$, applied cathodic current density $30.9 \mathrm{~mA} / \mathrm{cm}^{2}$, and solution temperature $30{ }^{\circ} \mathrm{C}$. The predicted PABA degradation efficiency under the optimum conditions was $98.9 \%$. Moreover, a test of PABA elimination at these conditions was performed, and approximate $97.2 \%$ removal was detected, confirming that the proposed models were well-reproducible in the design range as expected.

It should be noted that the optimization of the real water/wastewater treatment process is more complicated than that of laboratory simulation. Real water and wastewater usually contain a variety of organic and inorganic compounds, which can participate in the redox reactions and affect the target pollutants transformation. For example, the presence of effluent organic matter could significantly influence the traditional peroxone oxidation of micropollutants in wastewater [32]. In addition, besides the treatment efficiency, the cost of the process is also important. For practical applications, the optimization of technical parameters needs to be further investigated.

\subsection{Possible Oxidation Mechanism}

Figure 5 describes the $\mathrm{HO} \bullet$ production in various processes. The degradation trends of $p \mathrm{CBA}$ are similar to those of PABA; the fastest reaction rate was detected in the compartmental E-peroxone process. As a famous $\mathrm{HO} \bullet$ probe compound, $p \mathrm{CBA}$ has a high reactivity with $\mathrm{HO} \bullet\left(k_{\mathrm{OH}, p C B A}=5 \times 10^{9} \mathrm{M}^{-1} \mathrm{~s}^{-1}\right)$ and its ozonation rate is very low $\left(k_{\mathrm{OH}, \mathrm{O} 3}<1 \mathrm{M}^{-1} \mathrm{~s}^{-1}\right)$ [24,32]. Therefore, the steady-state concentrations of $\mathrm{HO} \bullet$ could be estimated from the slopes of curves in Figure 5, and their values were as follows: electrolysis $\left(\sim 3.0 \times 10^{-14} \mathrm{~mol} / \mathrm{L}\right)<$ ozonation $\left(\sim 3.9 \times 10^{-14} \mathrm{~mol} / \mathrm{L}\right)<$ E-peroxone $\left(\sim 4.2 \times 10^{-13} \mathrm{~mol} / \mathrm{L}\right)<$ compartmental E-peroxone $\left(\sim 6.4 \times 10^{-13} \mathrm{~mol} / \mathrm{L}\right)$.

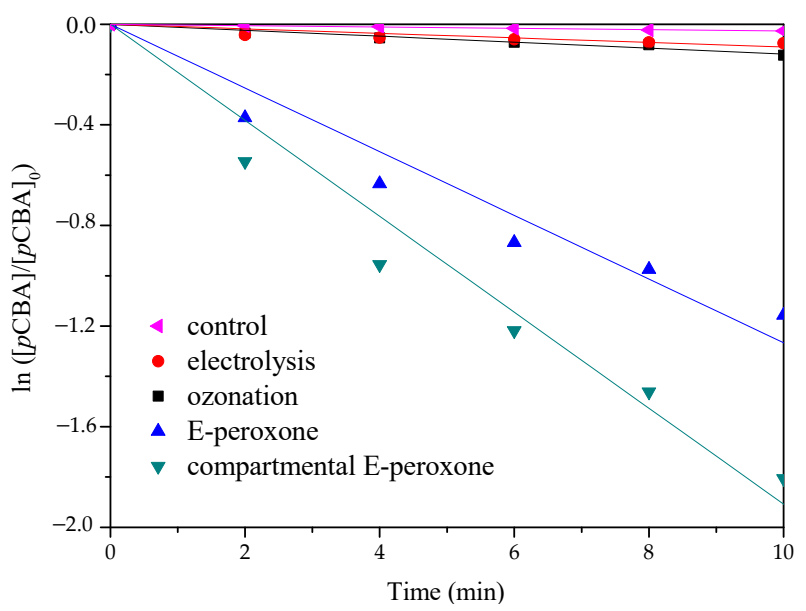

Figure 5. Time-dependent decay of $p \mathrm{CBA}$ in various treatment processes. (Gas flow rate $=0.2 \mathrm{~L} / \mathrm{min}$; Inlet $\mathrm{O}_{3}$ concentration $=\sim 20 \mathrm{mg} / \mathrm{L}$; Applied current $=20 \mathrm{~mA} / \mathrm{cm}^{2}$; Temperature $=25 \pm 2{ }^{\circ} \mathrm{C}$ ). 
The most important difference between E-peroxone with and without CEM is the separation of cathodic and anodic reactions. The above observations suggest that this separation could promote the $\mathrm{HO} \bullet$ generation. In general, in the E-peroxone system, $\mathrm{HO} \bullet$ can be produced via chain reactions of peroxone and cathodic ozone reduction (Equations (8) and (9)) $[11,16]$. As shown in Figure 6, with the presence of CEM in the electrochemical reactor, the cathodic reactions could cause the solution $\mathrm{pH}$ increase in the cathode chamber. When $1 \mathrm{~L}$ reaction solution was circulated between the cathode chamber and the feed tank (the solution in the anode chamber was circulated separately by another peristaltic pump), the solution $\mathrm{pH}$ increased from 6.9 to 10.7 within 2 min, and $\mathrm{pH} 11.2$ was detected at 10-min treatment. In contrast, in the undivided E-peroxone process, the solution $\mathrm{pH}$ decreased to 6.1 after $10 \mathrm{~min}$. As reported previously, the high production of $\mathrm{H}_{2} \mathrm{O}_{2}$ could be produced at lower $\mathrm{pH}$ values (e.g., $\mathrm{pH}<3$ ) or higher $\mathrm{pH}$ values (e.g., $\mathrm{pH}>7$ ) [33]. Under alkaline conditions, the reduction of oxygen would be Equation (10) [33]; the produced $\mathrm{HO}_{2}{ }^{-}$could act as an initiator for the chain reactions of $\mathrm{HO} \bullet$. To verify the enhanced $\mathrm{H}_{2} \mathrm{O}_{2}$ production, its formation in the two circulating systems was measured (Figure 7). The $\mathrm{H}_{2} \mathrm{O}_{2}$ yield in the cathode chamber was higher than that in the E-peroxone system without $\mathrm{CEM}$, confirming that the independent cathodic reaction is beneficial to the accumulation of $\mathrm{H}_{2} \mathrm{O}_{2}$.

$$
\begin{gathered}
\mathrm{O}_{3}+\mathrm{e}^{-} \rightarrow \mathrm{O}_{3}^{-} \bullet \text { at cathode } \\
\mathrm{O}_{3}^{-} \bullet+\mathrm{H}_{2} \mathrm{O} \rightarrow \mathrm{HO} \bullet+\mathrm{O}_{2}+\mathrm{OH}^{-} \\
\mathrm{O}_{2}+2 \mathrm{H}^{+}+2 \mathrm{e}^{-} \rightarrow \mathrm{HO}_{2}^{-}+\mathrm{OH}^{-} \\
\mathrm{H}_{2} \mathrm{O}_{2} \rightarrow \mathrm{HO}_{2} \bullet+\mathrm{H}^{+}+\mathrm{e}^{-} \\
\mathrm{HO}_{2} \bullet \rightarrow \mathrm{O}_{2}+\mathrm{H}^{+}+\mathrm{e}^{-}
\end{gathered}
$$

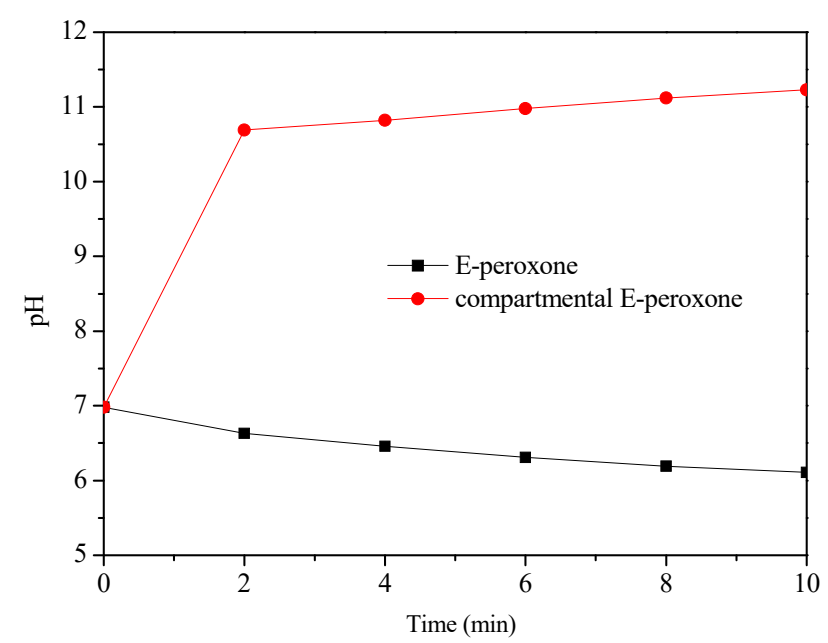

Figure 6. Profiles of $\mathrm{pH}$ in the E-peroxone and compartmental E-peroxone (cathode chamber) process. $\left(\right.$ Gas flow rate $=0.2 \mathrm{~L} / \mathrm{min}$; Inlet $\mathrm{O}_{3}$ concentration $=\sim 20 \mathrm{mg} / \mathrm{L} ;$ Applied current $=20 \mathrm{~mA} / \mathrm{cm}^{2}$; Temperature $=25 \pm 2{ }^{\circ} \mathrm{C}$ ). 


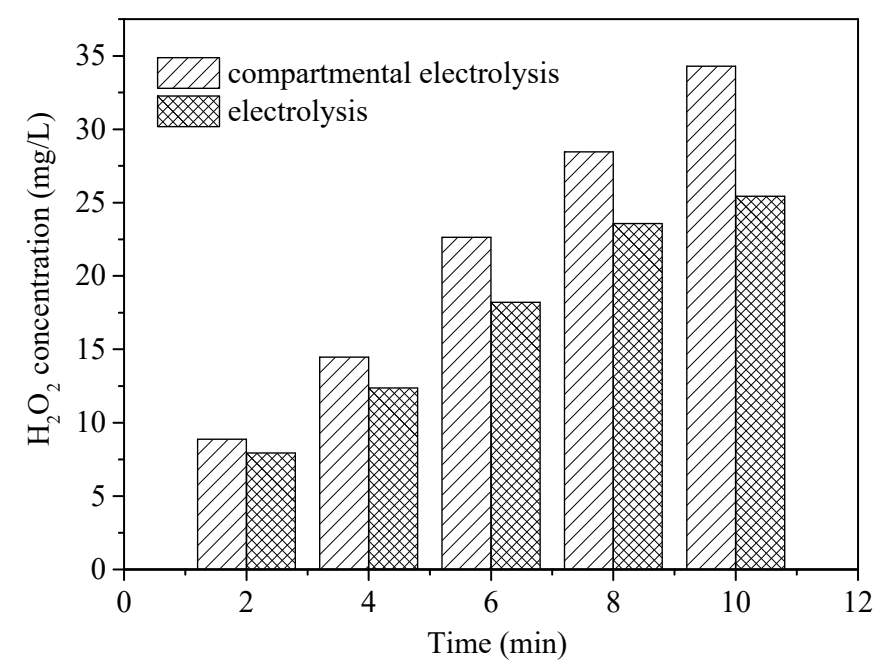

Figure 7. $\mathrm{H}_{2} \mathrm{O}_{2}$ generation in the electrolysis and compartmental electrolysis (cathode chamber) systems $\left(\mathrm{O}_{2}\right.$ flow rate $=0.2 \mathrm{~L} / \mathrm{min}$; Applied current $=20 \mathrm{~mA} / \mathrm{cm}^{2} ;$ Temperature $\left.=25 \pm 2{ }^{\circ} \mathrm{C}\right)$.

Besides providing favorable reaction conditions for the generation of $\mathrm{H}_{2} \mathrm{O}_{2}$ and $\mathrm{HO} \bullet$ in the cathode chamber, the compartmental E-peroxone could also reduce the $\mathrm{H}_{2} \mathrm{O}_{2}$ decomposition at the anode. In fact, CEM had a selective permeability that could prevent the anions' transfer to the anode. Thus, $\mathrm{HO}_{2}{ }^{-} / \mathrm{OH}^{-}$could react fully with ozone in the cathode chamber in the compartmental E-peroxone process. In contrast, the electrogenerated $\mathrm{H}_{2} \mathrm{O}_{2}$ would be consumed at the anode in the E-peroxone system without CEM (Equations (11) and (12)) [33]. Figure S3 shows that changing the reaction sequence of compartmental E-peroxone (i.e., the solution flowed through the anode chamber first and then flowed into the cathode chamber) reduced the HO• production amount and PABA degradation, but still yields higher efficiency than undivided conventional E-peroxone (Figure 2). Hence, the reduction of anodic side reactions is another possible reason for the high performance of the compartmental E-peroxone process.

\section{Conclusions}

In summary, a novel compartmental E-peroxone process was demonstrated for its efficiency in aqueous emerging contaminant PABA elimination. While sole electrolysis or ozonation could not degrade the target pollutant effectively, the combined E-peroxone oxidation yields synergistic PABA removal, and the separation of cathodic and anodic reactions further improved the treatment efficiency. HO• was the dominant oxidant for PABA degradation and the reaction conditions that favor the $\mathrm{HO} \bullet$ generation could promote the contaminant destruction rate. Based on the RSM analysis, the influences of operational parameters were optimized. To restate, the treatment efficiency was not only affected by each operating parameter, but also the interaction between different parameters should be noted. The alkaline environment in the cathode chamber, the reduction of anodic side reactions, and the enhancement of the reactant mass transfer during solution circulating were beneficial to the formation of $\mathrm{HO} \bullet$ via the peroxone reactions, thereby improving the degradation rate of PABA in the compartmental E-peroxone process. Considering the high efficiency and practicality of this process, it has the potential for emerging contaminants removal from water and wastewater.

Supplementary Materials: The following are available online at https: / www.mdpi.com/article / 10.3390/w13212961/s1, Figure S1 Residuals vs. Predicted plot for PABA removal efficiency at 10 min, Figure S2 Two-dimensional contour plots of the PABA degradation efficiency of compartmental E-peroxone in terms of two independent variables: (a) inlet gaseous ozone concentration and initial solution $\mathrm{pH},(\mathrm{b})$ solution temperature and initial solution $\mathrm{pH}$, (c) current density and inlet gaseous ozone concentration, (d) solution temperature and inlet gaseous ozone concentration, (e) 
current density and initial solution $\mathrm{pH}$, (f) solution temperature and current density, Figure S3 PABA and $p C B A$ degradation in the compartmental E-peroxone process with anodic reactions followed by cathodic reactions: (a) removal ratio and (b) the pseudo first-order reaction kinetics (Gas flow rate $=0.2 \mathrm{~L} / \mathrm{min}$; Inlet $\mathrm{O}_{3}$ concentration $=\sim 20 \mathrm{mg} / \mathrm{L} ;$ Applied current $=20 \mathrm{~mA} / \mathrm{cm}^{2}$; Temperature $=25 \pm 2{ }^{\circ} \mathrm{C}$ ).

Author Contributions: Conceptualization, D.W. and G.L.; Investigation, Y.L., Q.L., L.W. and P.Z.; Writing-Original Draft Preparation, D.W. and Y.L.; Writing-Review \& Editing, all authors. All authors have read and agreed to the published version of the manuscript.

Funding: This research was funded by the National Natural Science Foundation of China (No. 51608167), the Fundamental Research Funds for the Central Universities (No. B200202112), the Scientific and Technological Project of Henan Province (No. 162102310057).

Institutional Review Board Statement: Not applicable.

Informed Consent Statement: Not applicable.

Data Availability Statement: Not applicable.

Conflicts of Interest: The authors declare no conflict of interest.

\section{References}

1. Miller, I.B.; Pawlowski, S.; Kellermann, M.Y.; Petersen-Thiery, M.; Moeller, M.; Nietzer, S.; Schupp, P.J. Toxic effects of UV filters from sunscreens on coral reefs revisited: Regulatory aspects for "reef safe" products. Environ. Sci. Eur. 2021, 33, 1-13. [CrossRef]

2. Astel, A.; Stec, M.; Rykowska, I. Occurrence and Distribution of UV Filters in Beach Sediments of the Southern Baltic Sea Coast. Water 2020, 12, 3024. [CrossRef]

3. Cahova, J.; Blahova, J.; Plhalova, L.; Svobodova, Z.; Faggio, C. Do Single-Component and Mixtures Selected Organic UV Filters Induce Embryotoxic Effects in Zebrafish (Danio rerio)? Water 2021, 13, 2203. [CrossRef]

4. Khan, J.; Sayed, M.; Shah, N.; Khan, S.; Zhang, Y.; Boczkaj, G.; Khan, H.; Dionysiou, D.D. Synthesis of eosin modified TiO2 film with co-exposed $\{001\}$ and $\{101\}$ facets for photocatalytic degradation of para-aminobenzoic acid and solar H2 production. Appl. Catal. B-Environ. 2020, 265, 118557. [CrossRef]

5. Dromgoole, S.H.; Maibach, H.I. Sunscreening agent intolerance: Contact and photocontact sensitization and contact urticaria. J. Am. Acad. Dermatol. 1990, 22, 1068-1078. [CrossRef]

6. Tsoumachidou, S.; Lambropoulou, D.; Poulios, I. Homogeneous photocatalytic oxidation of UV filter para-aminobenzoic acid in aqueous solutions. Environ. Sci. Pollut. Res. 2016, 24, 1113-1121. [CrossRef] [PubMed]

7. Tsoumachidou, S.; Velegraki, T.; Poulios, I. TiO2photocatalytic degradation of UV filter para-aminobenzoic acid under artificial and solar illumination. J. Chem. Technol. Biotechnol. 2015, 91, 1773-1781. [CrossRef]

8. Faka, V.; Tsoumachidou, S.; Moschogiannaki, M.; Kiriakidis, G.; Poulios, I.; Binas, V. ZnWO4 nanoparticles as efficient photocatalyst for degradation of para-aminobenzoic acid: Impact of annealing temperature on photocatalytic performance. J. Photochem. Photobiol. A Chem. 2020, 406, 113002. [CrossRef]

9. Nie, M.; Zhang, W.; Yan, C.; Xu, W.; Wu, L.; Ye, Y.; Hu, Y.; Dong, W. Enhanced removal of organic contaminants in water by the combination of peroxymonosulfate and carbonate. Sci. Total Environ. 2018, 647, 734-743. [CrossRef]

10. Yao, J.; Yu, B.; Li, H.; Yang, Y. Interfacial catalytic and mass transfer mechanisms of an electro-peroxone process for selective removal of multiple fluoroquinolones. Appl. Catal. B Environ. 2021, 298, 120608. [CrossRef]

11. Kishimoto, N.; Nakagawa, T.; Asano, M.; Abe, M.; Yamada, M.; Ono, Y. Ozonation combined with electrolysis of 1,4-dioxane using a two-compartment electrolytic flow cell with solid electrolyte. Water Res. 2008, 42, 379-385. [CrossRef]

12. Yuan, S.; Li, Z.; Wang, Y. Effective degradation of methylene blue by a novel electrochemically driven process. Electrochem. Commun. 2013, 29, 48-51. [CrossRef]

13. Wu, N.; Zhang, R.; Lu, G.; Lin, Q.; Liu, F.; Li, Y. Degradation of Octocrylene Using Combined Ozonation and Electrolysis Process: Optimization by Response Surface Methodology. CLEAN—Soil Air Water 2017, 45, 1500664. [CrossRef]

14. Yao, W.; Fu, J.; Yang, H.; Yu, G.; Wang, Y. The beneficial effect of cathodic hydrogen peroxide generation on mitigating chlorinated by-product formation during water treatment by an electro-peroxone process. Water Res. 2019, 157, 209-217. [CrossRef]

15. Li, Y.; Shen, W.; Fu, S.; Yang, H.; Yu, G.; Wang, Y. Inhibition of bromate formation during drinking water treatment by adapting ozonation to electro-peroxone process. Chem. Eng. J. 2014, 264, 322-328. [CrossRef]

16. Wu, D.; Lu, G.; Yao, J.; Zhou, C.; Liu, F.; Liu, J. Adsorption and catalytic electro-peroxone degradation of fluconazole by magnetic copper ferrite/carbon nanotubes. Chem. Eng. J. 2019, 370, 409-419. [CrossRef]

17. Wu, D.; Lu, G.; Zhang, R.; Lin, Q.; Yao, J.; Shen, X.; Wang, W. Effective degradation of diatrizoate by electro-peroxone process using ferrite/carbon nanotubes based gas diffusion cathode. Electrochim. Acta 2017, 236, 297-306. [CrossRef]

18. Bakheet, B.; Yuan, S.; Li, Z.; Wang, H.; Zuo, J.; Komarneni, S.; Wang, Y. Electro-peroxone treatment of Orange II dye wastewater. Water Res. 2013, 47, 6234-6243. [CrossRef] [PubMed] 
19. Wang, H.; Bakheet, B.; Yuan, S.; Li, X.; Yu, G.; Murayama, S.; Wang, Y. Kinetics and energy efficiency for the degradation of 1,4-dioxane by electro-peroxone process. J. Hazard. Mater. 2015, 294, 90-98. [CrossRef] [PubMed]

20. Wu, D.; Zhou, C.; Lu, G.; Zhou, Y.; Shen, Y. Simultaneous membrane fouling mitigation and emerging pollutant benzophenone-3 removal by electro-peroxone process. Sep. Purif. Technol. 2019, 227, 115715. [CrossRef]

21. Zhang, Y.; Zuo, S.; Zhang, Y.; Ren, G.; Pan, Y.; Zhang, Q.; Zhou, M. Simultaneous removal of tetracycline and disinfection by a flow-through electro-peroxone process for reclamation from municipal secondary effluent. J. Hazard. Mater. 2019, 368, 771-777. [CrossRef]

22. Clesceri, L.S.; Greenberg, A.E.; Eaton, A.D. Standard Methods for the Examination of Water and Wastewater, 20th ed.; American Public Health Association: Washington, DC, USA, 1998.

23. Sellers, R.M. Spectrophotometric determination of hydrogen peroxide using potassium titanium(IV) oxalate. Analyst 1980, 105, 950-954. [CrossRef]

24. Von Gunten, U. Ozonation of drinking water: Part I. Oxidation kinetics and product formation. Water Res. 2003, 37, 1443-1467. [CrossRef]

25. García-Morales, M.; Roa-Morales, G.; Barrera-Díaz, C.E.; Bilyeu, B.; Rodrigo, M.A. Synergy of electrochemical oxidation using boron-doped diamond (BDD) electrodes and ozone $\left(\mathrm{O}_{3}\right)$ in industrial wastewater treatment. Electrochem. Commun. 2012, 27, 34-37. [CrossRef]

26. Li, K.; Xu, L.; Zhang, Y.; Cao, A.; Wang, Y.; Huang, H.; Wang, J. A novel electro-catalytic membrane contactor for improving the efficiency of ozone on wastewater treatment. Appl. Catal. B Environ. 2019, 249, 316-321. [CrossRef]

27. Nawrocki, J.; Kasprzyk-Hordern, B. The efficiency and mechanisms of catalytic ozonation. Appl. Catal. B Environ. 2010, 99, 27-42. [CrossRef]

28. Niazmand, R.; Jahani, M.; Sabbagh, F.; Rezania, S. Optimization of Electrocoagulation Conditions for the Purification of Table Olive Debittering Wastewater Using Response Surface Methodology. Water 2020, 12, 1687. [CrossRef]

29. Hamid, M.A.A.; Aziz, H.A.; Yusoff, M.S.; Rezan, S. Optimization and Analysis of Zeolite Augmented Electrocoagulation Process in the Reduction of High-Strength Ammonia in Saline Landfill Leachate. Water 2020, 12, 247. [CrossRef]

30. Cussler, E.L. Diffusion: Mass Transfer in Fluid Systems, 3rd ed.; Cambridge University Press: Cambridge, UK, 2009.

31. Von Sonntag, C.; von Gunten, U. Chemistry of Ozone in Water and Wastewater Treatment from Basic Principles to Applications; IWA Publishing: London, UK, 2012.

32. Lee, Y.; Kovalova, L.; McArdell, C.S.; von Gunten, U. Prediction of micropollutant elimination during ozonation of a hospital wastewater effluent. Water Res. 2014, 64, 134-148. [CrossRef] [PubMed]

33. Zhou, M.; Yu, Q.; Lei, L. The preparation and characterization of a graphite-PTFE cathode system for the decolorization of C.I. Acid Red 2. Dye. Pigment. 2008, 77, 129-136. [CrossRef] 